Eero Autio

\title{
THE PERMIAN ANIMAL STYLE
}

This is a copy of the article from printed version of electronic journal

\section{Folklore Vol. $18 \& 19$}

ISSN 1406-0957

Editors Mare Kõiva \& Andres Kuperjanov \& Väino Poikalainen \& Enn Ernits

Published by the Folk Belief and Media Group of ELM

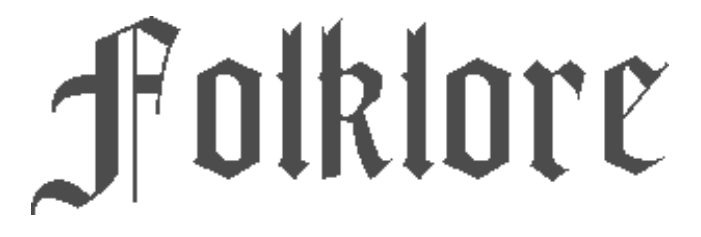

\section{Electronic Journal of Folklore}

Electronic version ISSN 1406-0949 is available from http://haldjas.folklore.eelfolklore

It's free but do give us credit when you cite! (C) Folk Belief and Media Group of ELM, Andres Kuperjanov

\section{Tartu 2001}




\section{THE PERMIAN ANIMAL STYLE}

\section{Eero Autio}

The picture on Figure 1 depicts a bronze-cast three-headed eagle with a tender mother's face depicted on its chest. This motif takes us straight to the ancient history of Finno-Ugric peoples living west of the Urals - Zyrian Komis, Permian Komis and Udmurts - and their art, most frequently referred to as 'the Permian animal style'. It was at its prime from the 6 th to the 8 th and 9 th c. and its end fell to the 14th c. Treating Permian art, we should bear in mind that the art of Ob-Ugrians is fairly similar to that of Permian peoples and that at the time there were also the Ob-Ugrians Mansis (or Voguls) living west of the Urals.

Permian bronze casts are $3-17 \mathrm{~cm}$ in size. They depict waterfowl, quadropeds and raptorial birds on whose chest is depicted a face or even a whole human figure (Figures 2-6). Just as common are figures of elk-headed humans (Figure 7) and humans, whose hands resemble the wings of a bird and head that of an elk, and underfoot whom is an animal usually called lizard (Figure 8). The latter motif is commonly called sulde. If only a human's head is replaced by an elk's, the motif is called an elk-human. Quite often there is a human or a face placed inbetween sulde-beings so that opposing elk heads arch above it. In addition to these, there are also motifs considered goddesses (Figure 10) and depicting a female face (Figure 11). For comparison, take a look at an Ob-Ugrian representation

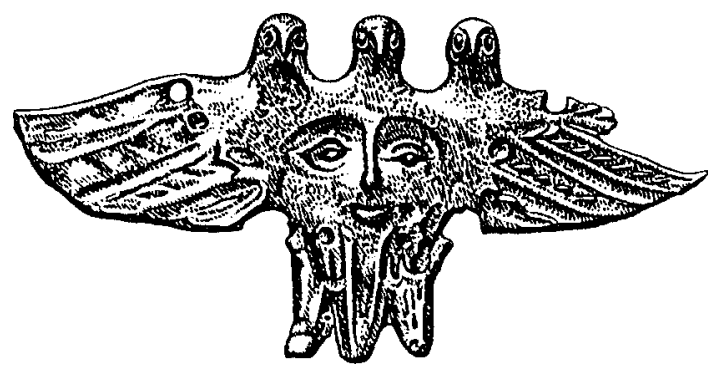

Figure 1. Three-headed eagle. 8th-9th century. Separate find. Permian-Komi region. The Teploukhov collection in the Perm Museum (Gribova 1975: table VI). 

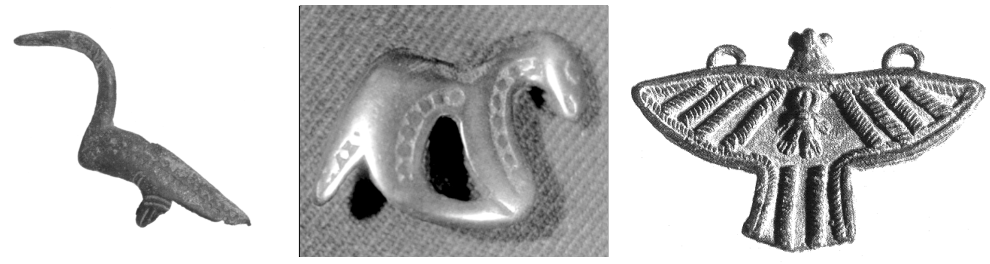
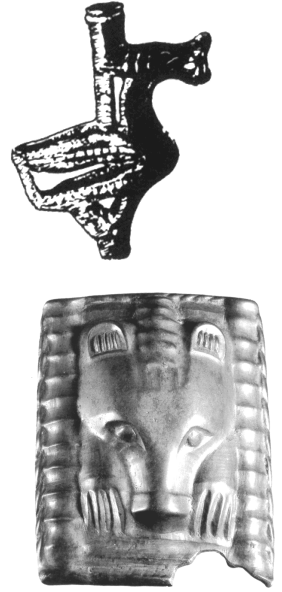

Figure 2 (left top corner). Swan. 7th-8th c. Treasure find of Skorodum, Perm Guberniya. $5 \times 9.2 \mathrm{~cm}$. Museum of Perm.

Figure 3 (left central). Pipe-shaped pendant. 6th-7th c. Upper Kama River, Perm Guberniya. $8.1 \times 6.4 \mathrm{~cm}$. Zelikman collection of Perm University.

Figure 4 (top central). Sable (?). 7th-8th c. Mikhailevo, Permian Komi. $2.5 \times 3.3 \mathrm{~cm}$. Museum of Perm.

Figure 5 (right top corner). Bird with a human on its chest, pendant. 10th-11th c. Separate find, Permian Komi. $4.3 \times 6.7 \mathrm{~cm}$. Teploukhov collection of the Museum of Perm.

Figure 6 (left bottom). Bear in sacrifice position, with loops for hanging on the back side. 4th/5th $c$ (?). Found by the Kyn River, Perm Guberniya. $8 \times 6.5 \mathrm{~cm}$. Teploukhov collection of the Museum of Perm.

Figure 7 (below, left). Human elk. 7th-8th c. Redikor, Perm Guberniya. $6.3 \times 2.6$ cm. Museum of Cherdyn (Oborin \& Chagin 1988: ill. 89).

Figure 8 (below, centre). Human-bird-elk (sulde). 7th-8th c. Troitsko-Pechora region, Komi. $9.2 \times 6.7 \mathrm{~cm}$. National History Museum, Moscow (Oborin \& Chagin 1988: 86).

Figure 9 (below, right). Face, a lizard beneath it and elk heads on its sides. 7 th-

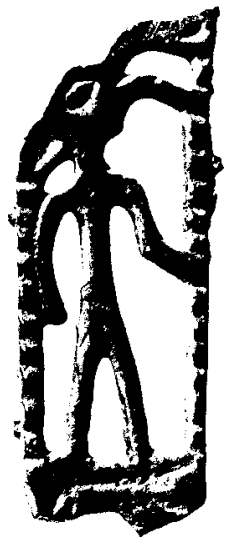

8th c. Found in 1985. Mogilnik village, Perm Guberniya. $3.6 x$ $2.7 \mathrm{~cm}$. Museum of Cherdyn (Oborin \& Chagin 1988: 100).
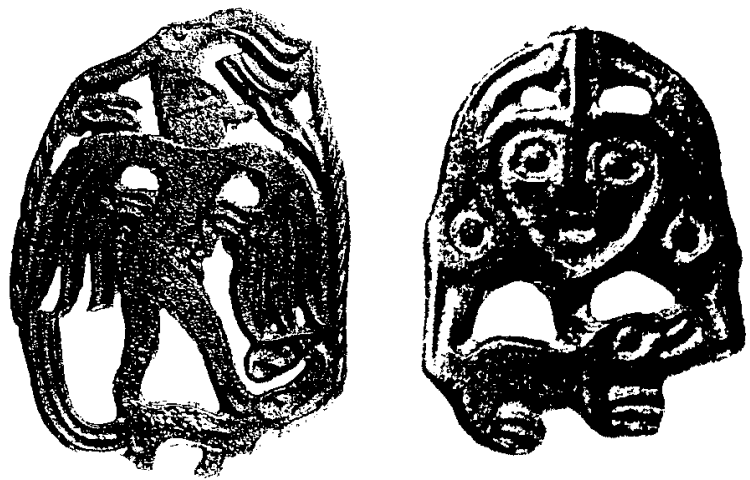


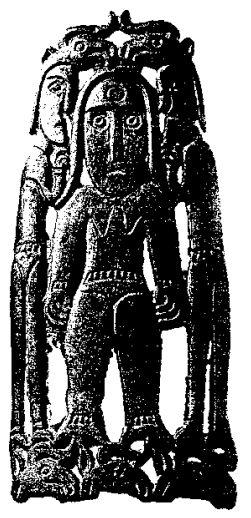

Figure 10 (left). A godess with men on her sides, and elk heads above and below. 6th-7th c. Found in 1948 at the mouth of the river Timsher merging into Kama River. Cherdyn region, Perm Guberniya. $14.5 \times 6.3 \mathrm{~cm}$. Museum of Cherdyn.

Figures 11-12. The motif of female face: 11 (below, left)from Gliadenovo, near Perm (Spitsyn 1906: 64). 12 (below, right) - an Ob-Ugrian version, Tobolsk (Spitsyn 1906: 62).
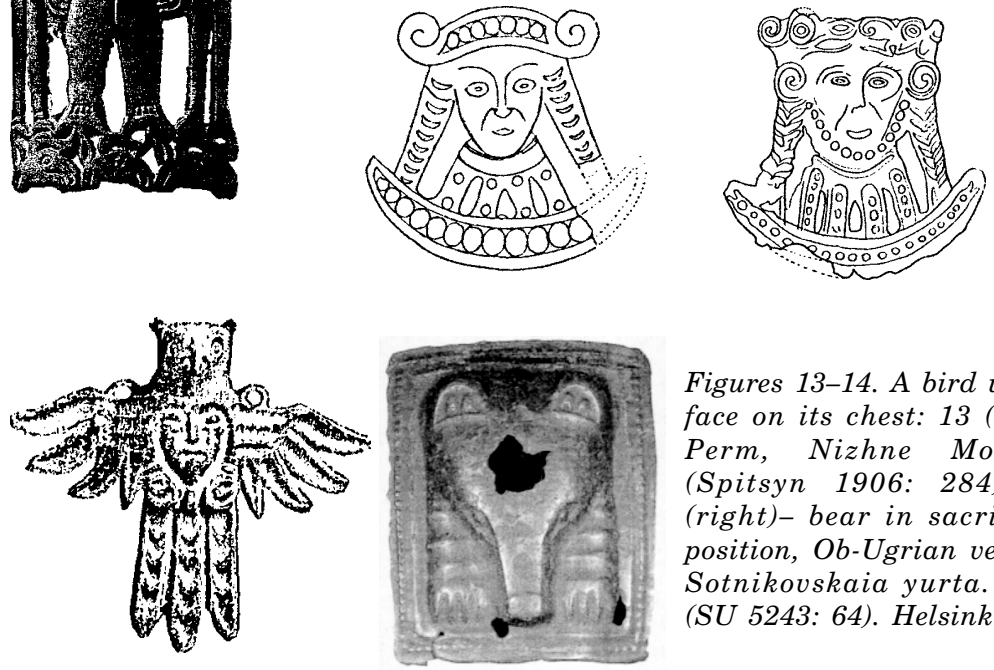

Figures 13-14. A bird with a face on its chest: 13 (left)Perm, Nizhne Moshevo (Spitsyn 1906: 284). 14 (right)- bear in sacrificial position, Ob-Ugrian version. Sotnikovskaia yurta. SKM (SU 5243: 64). Helsinki.

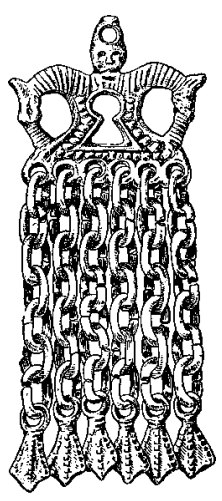

Figures 15-16. Pendants with horse motif: 15 (left)-Mikhailevo. 16 (right)- Uria. Both from 6th9th c. Smirnov 1952, XL: 10 and 8. Figure 17 (below). Pipe-shaped pendant with the motif of two animals with their noses touching. (Gribova 1975: insert XII).
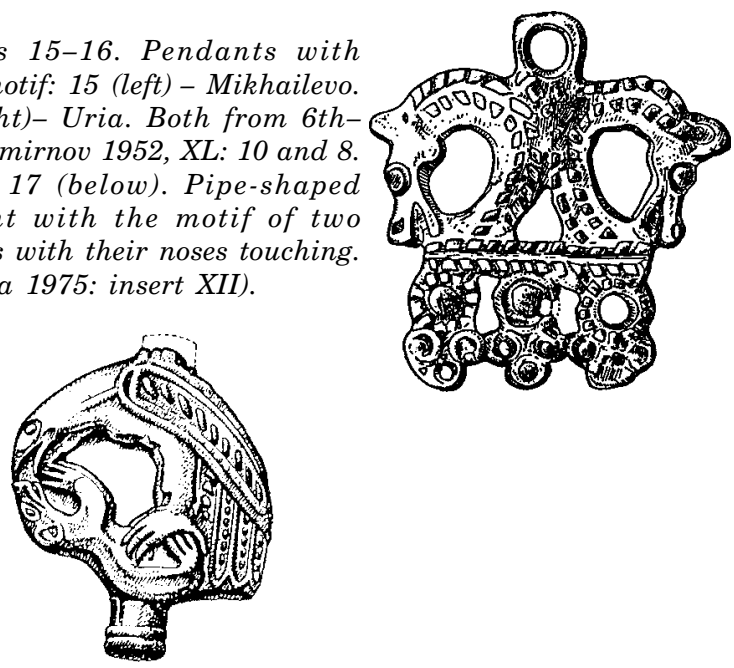
similar to the latter (Figure 12). There are notable similarities also in the case of other motifs (Figures 13-14). A separate group among Permian and Ob-Ugrian bronze casts is formed by items classified as women's adornments, such as pendants with horse motif (Figures 15-16) and so-called pipe-shaped pendants depicting two different animals (Figure 17).

Permian bronze casts have been found at excavations of cemeteries, strongholds and settlements, among treasure finds, in caves and by chance. Cemeteries, places of sacrifice and hidden treasures were sacred for local people and looting these would have been equal to condemning oneself to death. However, Russian invaders took no heed of this: besides furs, the opportunity to loot sacred places was the incentive to head east. Soldiers did the dirty work and princes kept the booty. They amassed collections, the most famous and numerous of which belonged to the Stroganov family (Gribova 1975: 101-105).

Later, some scholars, for example A. Teploukhov and M. Selikman supplemented their collections with bronze casts. Naturally, there are plenty of casts found during archaeological excavations and acquired in collection work that are kept in the Museum of Perm and the Perm University collections. In addition to these, casts are kept in museums in Cherdyn and Syvtyvkar, in the Hermitage in St. Petersburg and the collections of the Moscow National History Museum. As to Ob-Ugrian casts, there is reason to mention the museums of Tomsk and Tobolsk. The total number of items representing Permian animal style is unknown. In the album published by A. Spitsyn (1906) there are pictures of nearly 500 bronze objects, but numerous casts have been found since then.

\section{BRONZE CASTS IN ESTONIAN AND FINNISH MUSEUMS}

Permian bronze casts reached Finland already in prehistoric times: for example a three-headed eagle with a face on its chest (Figure 18), and pendants with horse motif, four of the kind found so far (Figure 19). Also, Finnish scientists have brought them along: J. R. Aspelin brought in 1858 and 1873 from Perm pendants with horse motif (SKM 1399: 100 and 111), pipe-shaped pendant with "ears" (1399: 101) and five fantastic bird representations (see Figures 21- 

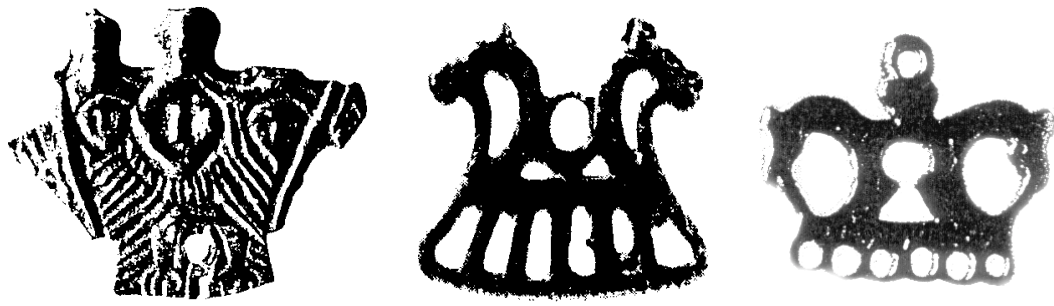

Figures 18-20. Bronze casts that reached Finland in prehistoric times: 18 (left)Juupajoki, West-Finland. Found in 1911. SKM (7881). Helsinki. 19 (centre)Juntusranta Suomussalmi, Huurre 1983, 359. 20 (right)-Vilusenharju, Tampere. $4.3 \times 5.2 \mathrm{~cm}$. SKM (18556:820). Helsinki.
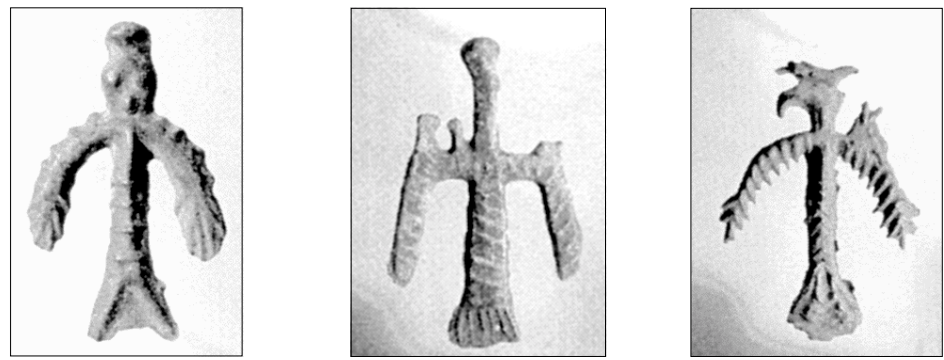

Figures 21-23. J. R. Aspelin brought in 1873 from "Perma" five "fantastic" birds. Here are presented three of them. Age: 4th-1st c BC (cf Smirnov 1952: 255), height 7-8 cm. SMK (1399:102). Helsinki.

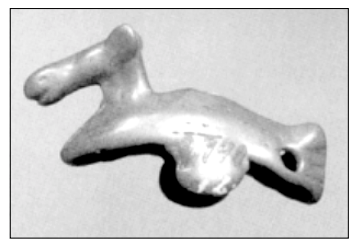

Figure 24. Waterfowl with elk head brought from Perm in 1893 by Axel Heikel. 6th-8th c. (cf Oborin \& Chagin 1988: ill. 63). Kocha, Cherdyn region. 2.5 $x 4.8 \mathrm{~cm}$. SKM (2940:72). Helsinki.

Figure 25. Artturi Kannisto brought in 1907 from Siberia a hollow "pendant" with horse motif (should be the handle of a fire iron, $c f$ Komi 1992, ill. 12, probably from 11th-12th c). Found in Verkhni Belym parish. $5.9 \times 7.5 \mathrm{~cm}$. SKM (4870:23). Helsinki.

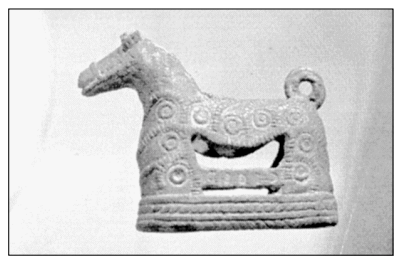


23). Axel Heikel bought in 1885 in Kasan a pendant with horse motif (SKM 2940: 71) and received from F. A. Teploukhov a cast with waterfowl motif (Figure 24), pendant adornments (2940: 67 and 68) and a pipe-shaped pendant with waterfowl motif (2940: 71). Artturi Kannisto brought from his Siberia expedition in 1907 a "pendant" representing a horse (Figure 25) and K. F. Karjalainen (18981902) brought from Siberia a cast with eagle motif (SKM SU 5243: 63) and a medallion depicting a bear in sacrificial position (Figure 14). M. S. Snamenski presented a Finnish expedition party a pendant with duck motif in 1887 Tobolsk (SKM 2599: 2). If we add to this the collection of K. R. Donner (SKM 6607: 1-21), from which one is hereby presented as a motif example (Figure 26), we can say that there are quite many Permian bronze casts in Finland.

Figure 26. A cast belonging to the collection brought from Siberia in 1914 by K. R. Donner. N. Kosarev (1984: 202203) connects this kind of motifs with beliefs concerning the tree of life and dates them to early Iron Age. Items belonging to the collection have been found in Tomsk Guberniya near Ragovitsa. Height ca $6.5 \mathrm{~cm}$. SKM (6607:1). Helsinki.

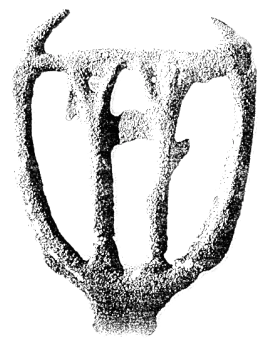

According to the archaeologist Heikki Pauts, no Permian bronze casts reached Estonia in prehistoric times. However, there are some in Estonia today. Paul von Krusenstern presented in 1873 the Tallinn History Museum 16 casts originating from the middle Pechora river. Of these, I hereby present a long-tailed bird (Figure 27), a boat similar to those on prehistoric petroglyphs (Figure 28), a elk-human (Figure 29) and casts depicting faces (Figures 30-32). In addition to the Krusenstern collection the museum maintains a cast that is known to originate from the Nizhni Novgorod region, presented to the museum by Katherina de la Gardie in 1891 (AM 197).

\section{OVERVIEW OF RESEARCH HISTORY}

Permian bronze casts are first mentioned in the travelogues of the Dutchman Nikolaus Witsen at the end of the 17th c. Russian travellers started writing about them in the mid-19th c. Western researchers heard of them in 1877 when the Finnish archaeologist J. R. Aspelin, who had conducted excavations in Russia, started pub- 

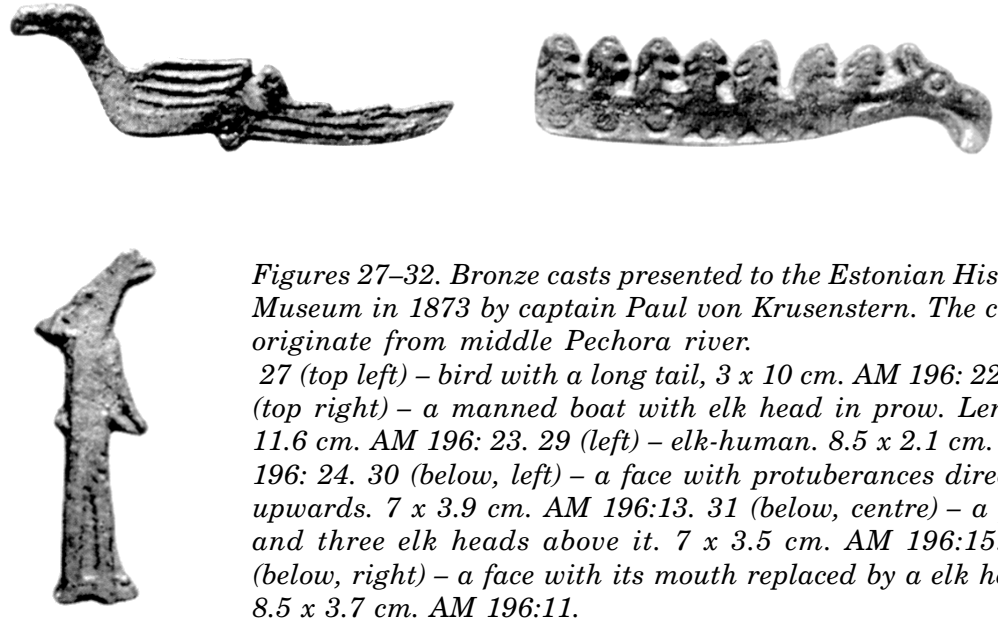

Figures 27-32. Bronze casts presented to the Estonian History Museum in 1873 by captain Paul von Krusenstern. The casts originate from middle Pechora river.

27 (top left) - bird with a long tail, $3 \times 10 \mathrm{~cm}$. AM 196: 22.28 (top right) - a manned boat with elk head in prow. Length $11.6 \mathrm{~cm}$. AM 196: 23. 29 (left) - elk-human. $8.5 \times 2.1 \mathrm{~cm}$. AM 196: 24. 30 (below, left) - a face with protuberances directed upwards. $7 \times 3.9 \mathrm{~cm}$. AM 196:13. 31 (below, centre) - a face and three elk heads above it. $7 \times 3.5 \mathrm{~cm}$. AM 196:15. 32 (below, right) - a face with its mouth replaced by a elk head. $8.5 \times 3.7 \mathrm{~cm}$. AM 196:11.
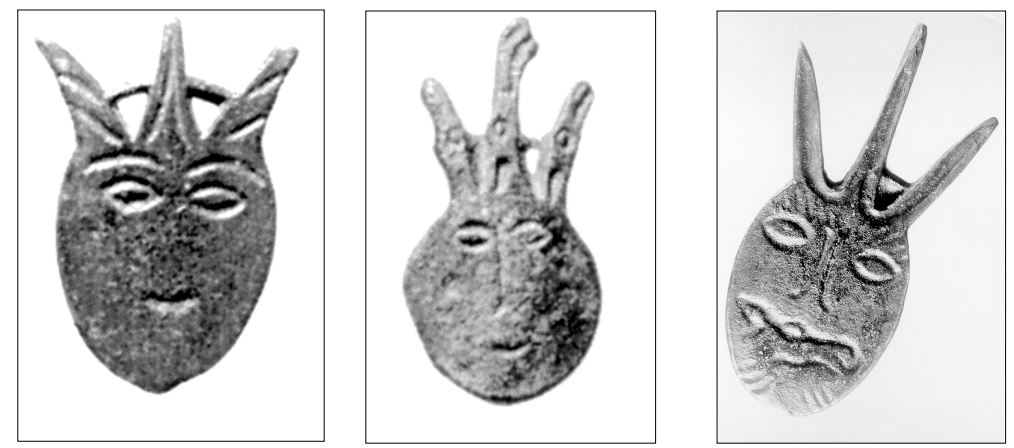

lishing pictures of bronze casts in the album series "Antiquités Nord Finno-Ougrien" (1877-1884). Aspelin thought already at that time that several motifs depict belief beings and gods.

Interest towards the Permian bronze casts arose in Russia at the end of the 19th c. In 1893, F. A. Teploukhov wrote an article on Permian Chuds, or Finno-Ugric peoples and their fantastic bronze pictures. In 1899, the archaeologist D. N. Anuchin published a lengthy article on the beliefs and art of the Chuds, where he pro- 
posed that the eagle motif reached Permian peoples from India via Scythians and Sarmates. Another archaeologist, A. Spitsyn, wrote about Permian bronze casts, connecting them with shamanism. In 1906, he published the bulky album "Shamanskie izobrazhenia", that due to pictorial material is useable even today. Spitsyn dates the prime of Permian art in the 7th-8th c. and looked for influences on its motifs to Iran and the Near East.

In 1887, a research party from Finland started out to East Russia and Siberia. The expedition party included O. Hj. Appelgren-Kivalo, who in 1912 published an article on Scythian-Permian applied art and proved that the motif of a bird with its wings spread and a face on its chest has its exemplar in the Greek drawings of the myth of Ganymedes, with only the face remaining of the whole human in the Permian region. The best-known Finnish archaeologists of the beginning of the 20th c. interested in Permian art was A. M. Tallgren (1885-1945). He conducted excavations in Russia also after the revolution, following the development of local archaeology and writing overviews of this to scientific journals in German, French, English, Swedish and Finnish. Of his treatments of Permian art let us mention only the article "Die Altpermische Pelzwarenperiode an der Petšora" (1934). Tallgren was of the opinion that Permian art received many influences from Central Asia via the Ob-Ugrians (Tallgren 1931: 123-124).

After the Russian revolution, a new stage started in research of Permian art. Attention was paid to different levels of material culture and their influence on beliefs and art. Following new methodical instructions, the archaeologist A. V. Shmidt (1927) explained the existence of the motif of the bird with a face on its chest in different cultural periods. He noticed that in the earliest period, only the eyes and mouth were depicted, in the next period the face, and only in the third the whole person. He excluded explanations based on the myth of Ganymedes and considered it a Scythian motif.

At the beginning of the 1950s, the opinion that most motifs are of Permian origin, started to become the canon in the Soviet Union. Thus, for example, A. V. Zbrueva (1959) maintained that the common Scythian motifs of winged lion and flying reindeer are not found in Permian art, where most common are the homely motifs of bear, wolf, elk, etc. As researcher of the Ananino culture (1500-900/800 
$\mathrm{BC}$ ), he took the origin of many motifs to be in that time and explained them with beliefs connected with the Sun, totemism, Godas-mother and myths.

The archaeologist A. Smirnov (1952) went even further in the search for the origin of motifs, dating it to 2-3 thousand years BC on the basis of items found in the Gorbunovo swamp. He maintained that Permian motifs have been influenced by the Antique Times, Scythians and Sarmates, the East and South, but that all this did not reach the content of the motifs. Smirnov emphasised the connection between the casts and shaman cult and totemism. In his interpretations he relied on beliefs, considering, for example, the motif of a female rider to be connected with traditional celebrations where spring was represented by a girl decorated with flowers, riding on a white horse. As Kronid Korepanov states in his article on research history (1978) that I have largely followed, Smirnov is considered a most spectacular researcher. In connection with the horse motif the best-known archaeologist is L. A. Golubeva, since her speciality is pendants with horse motif, so much adored by women (1966), and women's adornments in general, be their motif the Sun (1978) or animals (1979).

\section{AN IMPULSE FROM THE KOLA PENINSULA - TOTEMISM?}

Excavations and research published on their material had significantly increased archaeological material and knowledge by the 1960s. However, the impulse important for interpretation of Permian art came from the Kola peninsula. In 1965, V. Charnoluski published "Legenda ob olene-cheloveke", containing among other Sami narratives from the Kola peninsula the legends of Meandash-reindeer. ${ }^{1}$ Meandash, living as a human and reindeer, married a Lapp girl and they had children. The legends, beliefs and customs connected with them are clearly totemistic. Working in the Hermitage, Charnoluski treated the Permian bronze casts with the motif of elk-human as pictorial counterparts for these Sami narratives.

Charnoluski's book draw attention. In 1972, L. S. Gribova published in a collection of articles on Komi ethnography an article on the interpretation of Permian bronze casts. Although Gribova did not 
agree with Charnoluski in all his proposed parallels, she used Meandash as the name for elk-human. This became fixed in professional literature and seems to be in use also in most recent works. Due to the scope of the topic, Gribova published her totemistic interpretations together with argumentation in "Permski zverinyi stil" (1975). Gribova was keen on Finno-Ugric decorative art, spoke Komi language and had in her youth heard Komi legends and beliefs. The most plausible of her explanations concerns the motif of two animals with their muzzles touching (Figure 17). Gribova disagrees with the interpretation that this motif depicts intertribal conflict. The said motif can also be found on women's pipe-shaped pendants that were worn either on chest or hips, implying that they depicted matters important or close for her, like love and marriage. Gribova's attempt to explain the emergence of different motifs with the emergence of new tribes does not seem plausible. However, her analysis on coherence of different motif parts could be an example for other researchers.

The researcher of Komi folk heritage A. S. Sidorov published in 1972 - in the same publication as Gribova - an article on bronze casts. Sidorov believes that single animal representations can be explained by totemism. The central motif of casts with several representations symbolises the creator of the world and the mother of humankind. Three eagle or elk heads refer, in addition to the totemistic group, also to the Sun. The Sun and the sky are also referred to by the wings of the sulde-beings, a remnant of an earlier era, as are the nose's similarity to a bird's peak and having three fingers. Explaining the frequency of the bird motif, Sidorov refers to the Permian Komi myth of the creation of the world. According to this, the primal mother Chyzh, or wild duck laid six eggs of which the world appeared. The lizard placed on the lower edge of bronze casts is, according to Sidorov, an opposing power hostile towards the Sun. To support his interpretation, he relates a belief connected with the lizard. Yet this does not make his explanation plausible, since on bronze casts lizard is also depicted as mount. 


\section{CRITICISM. SHAMANISM AS AN OFFERED EXPLANATION}

Academician V. A. Rybakov criticises (1979) Charnoluski for not knowing the mythology of Permian peoples well enough, and Gribova for being overeager towards totemism. But eager seems also Rybakov himself when he states that the elk-headed staff claimed to be an instrument of a shaman, found from the Oleni Island cemetery on Lake Onega (Figure 33) fits "exactly" (p. 18) the symbol placed above the shaman standing between sulde-beings on Figure 34. Based on their similarity, Rybakov concludes that Figure 35 represents a winged shaman and that on Figure 36 the bird's task is to help the shaman into heavens.

Rybakov received additional support from L. V. Chizhova, who reproved Gribova and Sidorov for not having used archaeological material. Chizhova (1982) takes under observation archaeological cultures and the development of shamanism. She goes as far as to even recog-
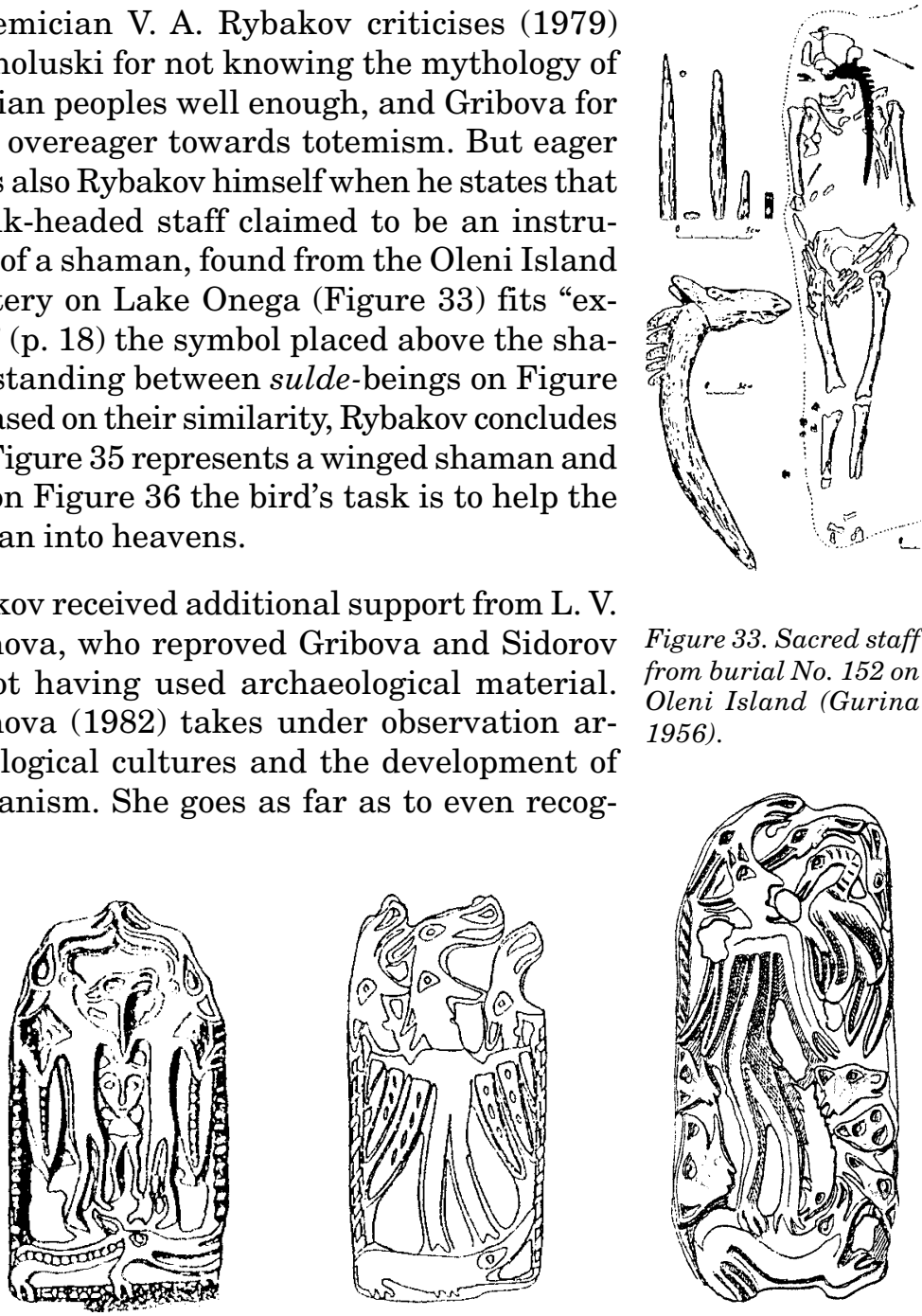

Figure 33. Sacred staff from burial No. 152 on Oleni Island (Gurina 1956).

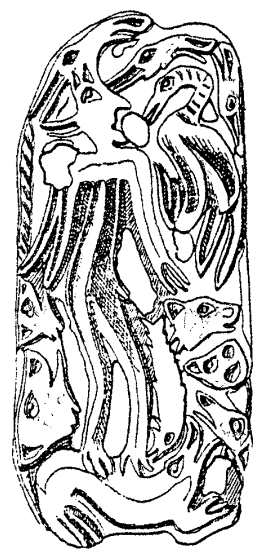

Figures 34-36. Some interpretations by Rybakov: 34 (left) - shaman. 35 (centre)winged shaman. 36 (right) - bird as a helping spirit. (Spitsyn 1906: 170 Peshkova, 117 Ukhta, 127 Ukhta). 
nise white and black shamans in the Permian bronze casts. A white shaman used an elk-head mask symbolising heaven while a black shaman used a an animal head-cover, visiting also the netherworld.

Noteworthy among Rybakov's interpretations is the claim that elks facing one another seem as if forming the firmament. The impression is indeed reverential, the human figures under the snouts as in a safe place. New and significant is that the lizard is seen as the symbol of the changing of day and night. Chizhova's most plausible explanations concern the married couple and family.

Siberian shamanism has always employed animal requisites, but shamans of Permian and other Finno-Ugric peoples have never used antlers nor animal head-covers. Signs of this can not be found on Lapp shaman drums or in the art of Ob-Ugrian peoples (Autio 1995). The elk-headed staff from Oleni Island can not be the attribute of a shaman since Karelian petroglyphs by the Vyg River depict a ritual procession with many participants holding in their hands animaland human head-shaped objects of cult. This elk-headed staff is more probably a symbol that implies the existence of contemporary totemism, as also believes Studzitskaia (1994).

\section{PLACES FOR SOULS TO STAY OR TO BE KEPT?}

Numerous researchers assume that the bronze casts were made for keeping the souls of the deceased. This is the explanation Gribova reached in her 1984 article on Heibida-Pedary bronze casts, although this did not keep her from emphasising totemism as well. Chizhova, also, was not content with her earlier explanations and returned to Permian bronze cast motifs in her 1987 article. Having studied the beliefs of Siberian native peoples connected with the soul, she concludes that only cast depictions of bear can be explained by totemism. All casts with multiple motifs of a human and some animal or bird, or maybe only a human or human head, would have been made as resting places for the soul.

Taking care of souls could have been reason important enough to cast bronze figures for their place of stay. Some Ob-Ugrian casts, especially those depicting a human with closed eyes, could, then, be the places for keeping the soul. However, the size of the casts (4-6 
$\mathrm{cm}$ ), their medallion-like shape and loops or holes for hanging give reason to believe that they are rather keepsakes than dwellings for souls. As for connecting a human with an animal or bird - this is more easily explained with totemism than with the keeping of souls.

\section{THE TREE OF LIFE IN INTERPRETATIONS}

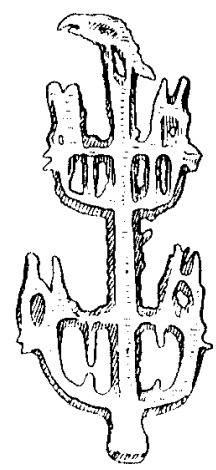

Figure 37. West Siberian bronze cast - a tree of life (Kosarev 1984: 203).
Recent decades have favoured interpretations based on beliefs concerning the tree of life. The archaeologist M. F. Kosarev has studied the past of Finno-Ugrians and maintains that (1984: 202) the relevant beliefs were common in the Copper and Bronze Ages, and especially in the Iron Age. Undoubtedly, among the pictures of bronze casts he has published there are those with the motif of a tree with its top and branches ending with animal heads (e.g. Figure 37). Thus beliefs concerning the tree of life do have a material counterpart, but this is not sufficient for the wide-scale explanation of all motifs as attempted by I. V. Ilina (1994) and Kronid Korepanov (1995). One certain case where the tree of life explanation can be used is the motif on Figure 38 where animal heads grow out of the head and hands of a human, forming as if a tree. Whether this has instead meant to represent the propagation of animals, remains for the viewer to ponder. According to Korepanov, the lizard denotes earth, from where the tree derives its strength, and according to Ilina the netherworld or hell.

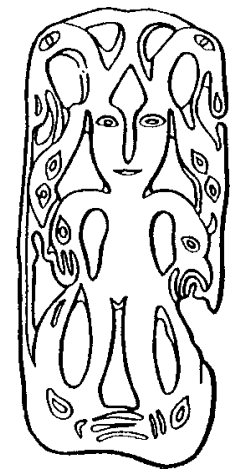

Figure 38. Permin bronze cast tree of life (Gribova 1975: VII).

\section{NEW INTERPRETATIONS AND METHODS}

The Udmurtian archaeologist Nadezhda Shutova gave in 1995 a presentation at the congress of Finno-Ugristics in Jyväskylä on the 
topic of an ancient Udmurtian goddess and the possibilities of reconstructing this goddess. She started the reconstruction by viewing pendants with the motif of horse heads facing different directions with human heads inbetween them and duck feet dangling on chains below (Figure 15). She believes that the horse heads symbolised the Sun horse and the changing of day and night, and the human head a goddess connected with both this and the netherworld.

The motif of a female rider and snake on the lower edge of the cast (Figure 39), according to Shutova, does not depict the fight between the Sun and netherworld, as proposed by Smirnov. Shutova claims that the relationship between the horse and snake is harmonious and peaceful. The female rider is the mother of everything in existence and the horse her means of transportation to both

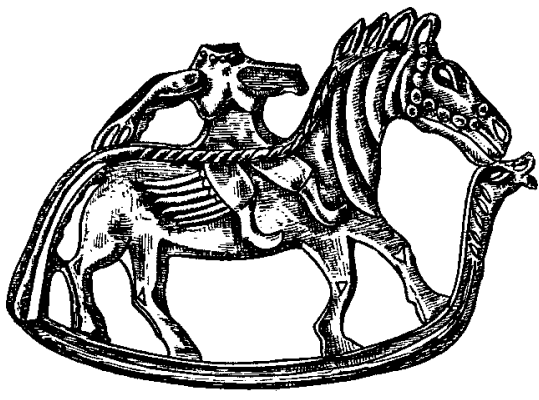

Figure 39. Female rider. Glazov region. 8th-9th c (Golubeva 1979: table 16:2). upper and lower worlds.

According to Udmurtian heritage records, the higher gods Inmar, Kvasia and Kyldysin were male. The latter was the God of earth and harvest as well as the protector of women and children. The word kyldys means in Permian 'creative', 'fertilizing', and -in 'woman', 'female (animal)', 'mother', 'mother-in-law'. Kyldysin used to live on Earth, but took offence by people's behaviour and went to heaven, or according to other records, under ground. The one in heaven became mixed with Inmar and the one under ground became Mu-Kyldysin, the God of fertility, who gave soul to the children, protected young mothers and the welfare of the kinsfolk. The corresponding god for Komis was Zarni-an, or golden woman, for Maris Shun-Shochynava, or the mother of everything in existence, and for Mansis Kaltash-ekva, the wife and sister of the highest god.

All these records Shutova unites with the bronze casts depicted on Figures 10, 40 and 41 and others resembling these, that clearly depict a goddess. She believes that the widely-known goddess impersonates a healthy and strong woman who was the beginning of 

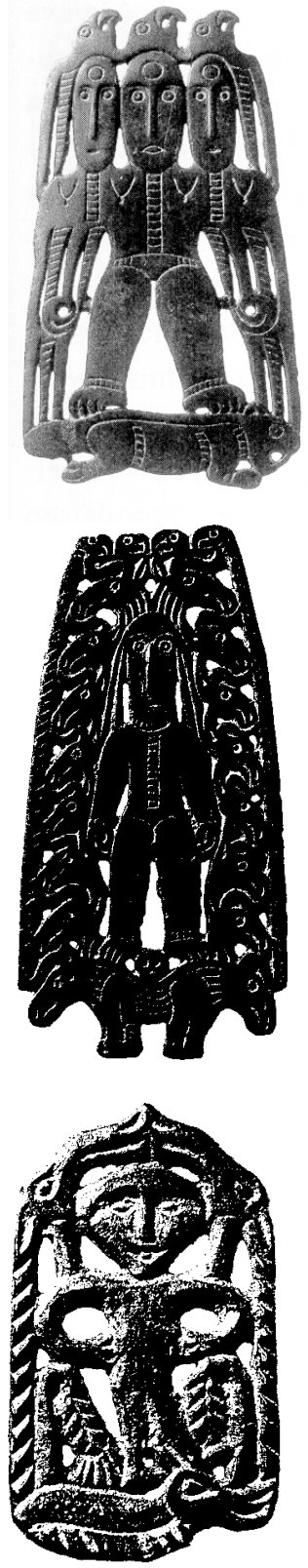

Figure 40 (top). Goddess. 7th-8th c. Found in 1911 from under tye roots of three old firs. Ust-Kaib village, Cherdyn region. $16.4 \times 9 \mathrm{~cm}$. Museum of Cherdyn.

Figure 41 (centre). Goddess. 7th-8th c. Found during the constructions of a dam at the mouth of the River Timsher in 1946. Cherdyn region. $16.2 \times 8 \mathrm{~cm}$. Museum of Cherdyn.

Figure 42 (bottom). "Barley God". 8th-9th c. Omelino (Lukoianov). Cherdyn region. Found in 1904, presented to the Museum of Cherdyn in 1950. $5.5 \times 3$ $\mathrm{cm}$.

everything created with the world, giving life to plants, animals and humans, and determining their fate. In this, birth, growing, death and rebirth became personified. The goddess became a male god at the beginning of the second millennium, maintaining the functions. Shutova has elaborated the change process in her 1998 article, where she also claims that the time Kyldysin spent on Earth symbolises the happy times and his taking offense the wars and suffering of the 16 th $\mathrm{c.}^{2}$

Shutova's reconstruction is a welcome addition to interpretations of bronze casts. This makes one want to expand the theory to include the motif of a human with heads of grain attached to the undersides of the arms (Figure 42). Uno Holmberg describes in his book "Permalaisten uskonto" a Udmurtian prayer that ends with the hope that Mu-Kyldysin would let the stalk bend "under the weight of grain" (Holmberg 1914: 200). Let it be added that the cast under discussion was found on a Chud field and that local inhabitants considered it the god of barley.

The most significant new method is described by the archaeologist Natalia Chesnokova (1988) 
in a work on 166 myth-related casts found from the land of the Komis. She gives them, based on their proportions, exact mathematical indices and classifies different types into main and subgroups. This allows also for casts with unknown places of finding to determine their age and place of origin. As expected, some animal motifs (type 6) are found from the whole area under discussion. Although type 1 (sulde) is found west of Pechora and type 4 (bird with a face on its chest) from upper Pechora, by the Vishera and tributaries of the Vychegda, they are the ones with the greatest number of similar features. In my opinion, these would support totemistic interpretations.

Chesnokova was not so much interested in totemism but the ancient myths of the Komis. In the article "The Myth of the Northern Sub-Urals" (1995) she claims that the myths were forgotten due to the early influences of Christianity, but that some fragments have been maintained in legends, epic and other songs as well as iconography, or picture motifs. She starts her observations with the waterfowl motif and indicates with drawings that in some cases the duck feet resemble elk heads, while in some cases the duck has an elk head. There are also casts with the motif of two ducks. To explain these, she relates a Permian Komi myth in which the duck swimming on the primeval ocean laid six eggs. Out of two hatched sons, who became two opposing gods - Jen and Omyl, good and evil. According to Chesnokova, chozh denotes uncle, relative and forefather. However, the duck of the creation myth is not chozh but chyzh, which as a word is a postposition denoting 'during', e.g. vezhon chyzh 'during a week', as a verb chyzhni 'to save', 'to collect', and the compound word chyzhiyv 'beest, the first milk after birthing'.

The semiotic differences between chozh and chyzh make the possibilities of explaining the features referring to duck and elk with the word chozh doubtful. Noteworthy is Chesnakova's conclusion that in all myth-related casts there is present "the complicated mythological image of the Premordial Bird chozh" (Chesnokova 1995: 51). In fact, the semiotic nuances of the word chyzh expand the meaning of the whole motif. I myself consider the duck to be the beginning of everything existing and its meaning being connected with time seems to indicate that only time has given everything existing 


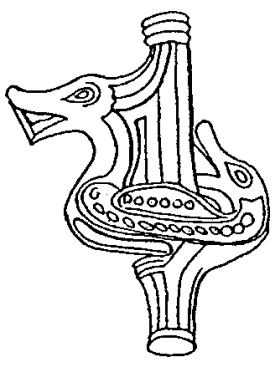

Figure 43. Pipe-shaped pendant with the motif of two waterfowls. Garamikha (Spitsyn 1906: 328).

its perceptible shape (Autio 2000: 84). Chesnokova's value lies in that she pays attention to the smallest details and treats bronze casts graphically. Most plausible among her interpretations is connecting the chyzh legend with the motif of two ducks (Figure 43).

\section{THE ICONOGRAPHIC TRADITION OF FINNO-UGRIC PEOPLES}

The archaeologist A. A. Formozov who is also knowledgeable in prehistoric art, maintains (1969: 228) that the Finno-Ugric peoples have an image tradition originating from the Stone Age that carries on the motifs of North-Russian metal casts. V. Oborin and G. Chagin suggest in their book "Iskusstvo Prikamia" (1988: 16) that the roots of this art go together with the Kapova cave paintings back to approximately 30,000 BC. Even if the age of the said paintings would be only 15,000 years (Obydenov \& Korepanov 1997: 13), the image tradition of Finno-Ugric peoples would be exceptionally long.

This, indeed, is the case. I have studied the motif where three rays, protuberances or heads extend from a human head, as depicted on Figures 30-32. The motif is found on the Iamazy-Tash cave painting in the South Urals, later also rock art of the Mid-Urals, scultpures of Fennoscandia and Siberia, ceramics of Samus IV, wood carvings of Minusinski, the seal of Mohenjo Daro, Permian bronze casts, Lapp shaman drums and Buriatian ongons. In my opinion, this motif symbolises dignity, ability and strength (Autio 1995: 17; 2000: 180).

The second motif, originating from the cave paintings of Kapova and Iamazy-Tash, concerns the numbers 4, 7, 10, 14 and 21. They appear in the form of lines, dots, parts of motifs and decorations. Credible information as to the meaning of the said numbers can be found from Boris Frolov's "Chisla v grafike paleolita" (1974). Frolov connects the numbers 7, 14 and 21 with phases of the Moon and the 


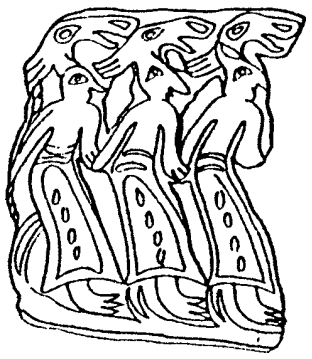

Figures 44-45. The number four: 44 (left) - suldewomen. Garamikha (Spitsyn 1906: 154). 45 (right)bird with a face on its chest. Kishert (Spitsyn 1906: 268).

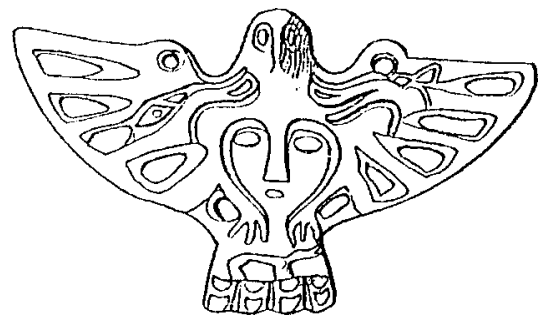

female menstrual cycle, and the number 10 with pregnancy, which lasts 10 Moon months.

Since presence of the numbers 4, 7 and 10 on Permian bronze casts is significantly apparent, I have studied them with the intention of determining whether they are connected with man, woman or lizard. For source material I have used Spitsyn's album (1906), Oborin and Chagin's publication (1988) and the Hermitage photo collection. I have only viewed pictures where decorations, parts of motifs, etc. can be counted, a total of 160 pictures. I classified the suldebeing as male if it had a beard or a protuberance between legs.

As the result of my research I can say that the numbers 4, 7 and 10 are found exclusively in connection with a female being (e.g. Figures 44-50). I also observed the frequency of the number 5, but it did not appear to have a clear connection with males despite the fact that in Ob-Ugrian beliefs 5 refers to man and 4 to woman. It is possible that the presence of five in case of female beings refers to the absence of males.

The numbers 4, 7 and 10 are significantly often also found in parts of the lizard motif and its decorations (e.g. Figures 46 and 48). I have observed a connection with fertility in the case of the lizard motif (e.g. Figures 48, 51-52). This fits to the explanation according to which lizard symbolised Earth and the under-world, the world of the dead. In Udmurtian beliefs, life was a gift from the deceased and the living received their souls from forefathers (Holmberg 1914: 51-53). When a Komi sowed a field, went hunting or fishing, he always asked the deceased for their blessing (Nalimov 1907: 10). 


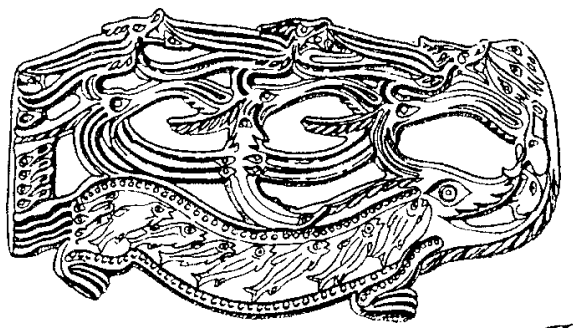

Figures 46-47. The number seven: 46 (left) - lizard with seven fish in its stomach. Nyrgynda (Spitsyn 1906: 108). 47 (below) - seven suldes. Peshkova (Spitsyn 1906: 152).
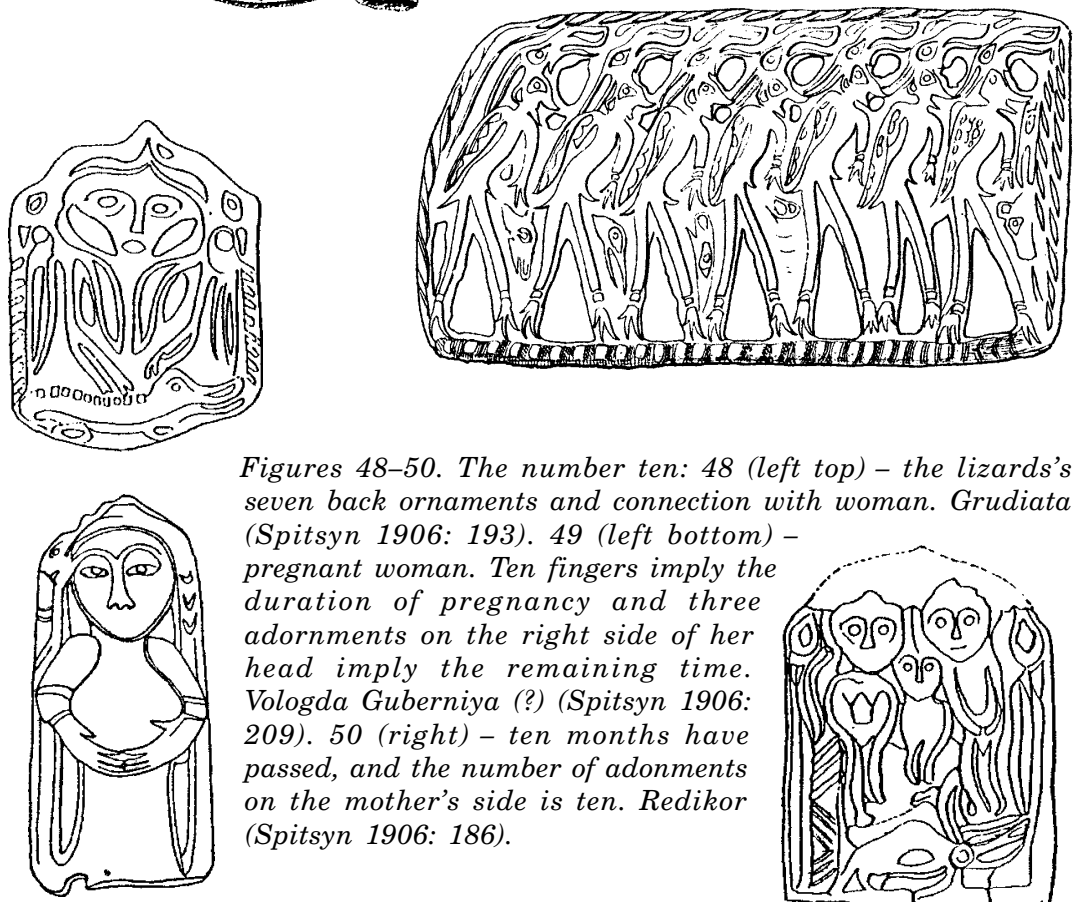

Figures 48-50. The number ten: 48 (left top) - the lizards's seven back ornaments and connection with woman. Grudiata (Spitsyn 1906: 193). 49 (left bottom)pregnant woman. Ten fingers imply the duration of pregnancy and three adornments on the right side of her head imply the remaining time. Vologda Guberniya (?) (Spitsyn 1906: 209). 50 (right) - ten months have passed, and the number of adonments on the mother's side is ten. Redikor (Spitsyn 1906: 186).
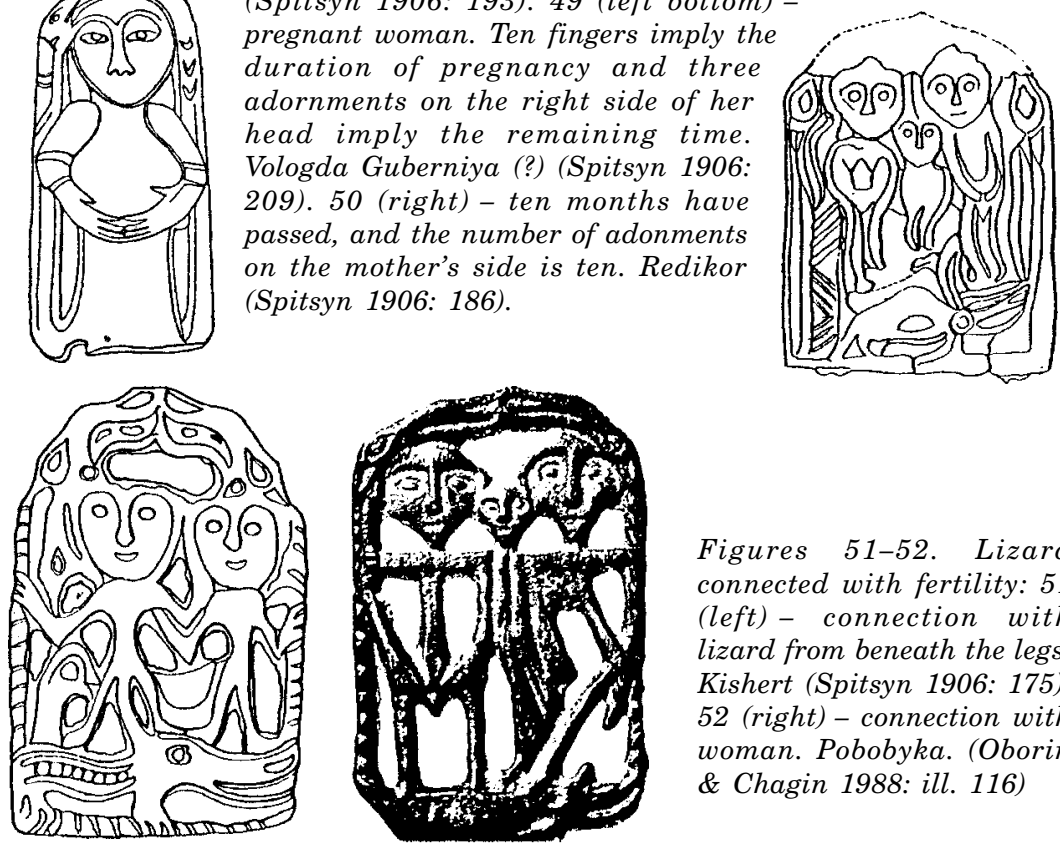

Figures 51-52. Lizard connected with fertility: 51 (left) - connection with lizard from beneath the legs. Kishert (Spitsyn 1906: 175). 52 (right) - connection with woman. Pobobyka. (Oborin \& Chagin 1988: ill. 116) 

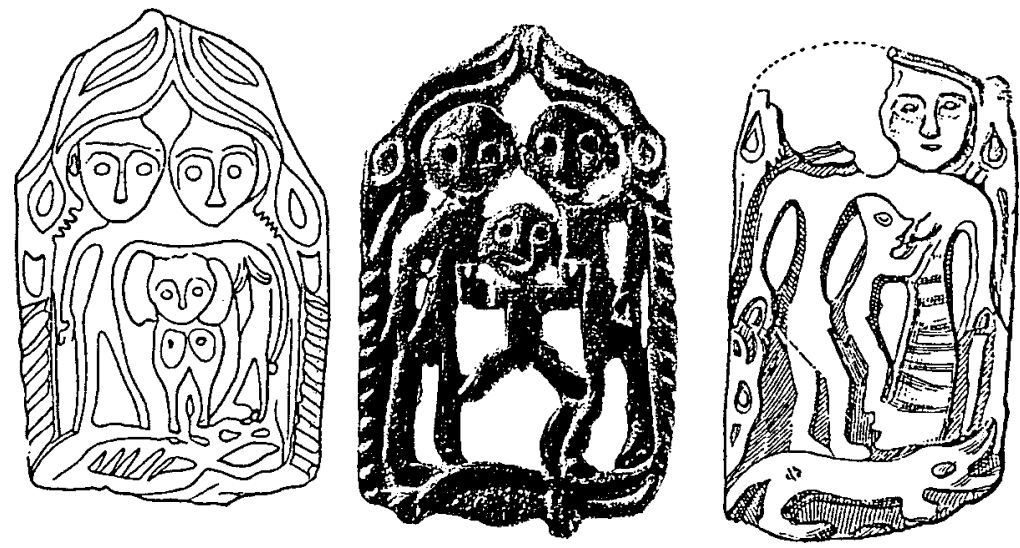

Figures 53-55. Motifs connected with childbirth: 53 - a girl was born! (Spitsyn 1906: 182). 54 - and a son! (Oborin \& Chagin 1988: ill. 126). 55 - family bliss (Spitsyn 1906: 183).

From the point of view of land, underground forces and fertility, time is the factor what makes growing possible. The numbers under discussion refer, also in connection with the lizard, to time and fertility. Thus, for example, the lizard on "family pictures" (Figures 53-55) is as important as the elk heads inspiring security.

\section{THE MOTIF CONNECTED WITH WOMEN'S LIFE}

Figure 56 depicts a nimble elk-horse and a rider on its back. Natalia Chesnokova (1995) has considered the rider the Komi hero Pera. However, the rider is a woman, as on other casts with the motif of a female rider. Counting the parts of the motif, we observe the following numbers. Behind the female rider are five elk heads, in my opinion referring the gender of the animal (bear) in the left corner. In front of the female rider there are two elk heads, thus making it a total of $5+2$ or 7 heads on the back of the elk-horse. Underneath the mount's feet are, instead of a lizard, seven animal heads (facing right). Counting these and the heads on the mount's back we reach the number 14 . On the lower left side there are three animal heads (facing up). Thus in the lower part there is a total of 10 heads. In front of the mount there is a bird. In its tail and wings is repeated the number four, referring to woman or the weeks 


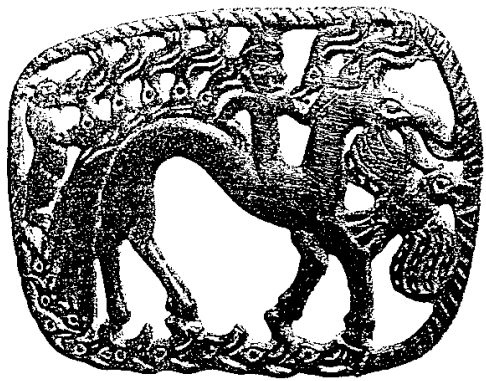

Figure 56. Elk-horse and female rider. 5th-6th c (Oborin \& Chagin 1988), 8th $c$ (Melnichug). Separate find from the 19th c. Perm Guberniya. $7 \times 9.3 \mathrm{~cm}$. The Selikman collection of Perm University.

of a month. The bird itself could, according to Chesnokova's interpretation, imply wedding or netherworld (Chesnokova 1995: 50), or simply be a guide.

Nadezhda Shutova believes it safest to presume the rider to be the mother of everything, who decides the fate of humans. The number 14 probably refers to ovulation, on the average occurring on the 14 th day of the menstrual cycle. If a woman does not wish to become pregnant, she needs to avoid sexual intercourse from the 7th to 21st day of the cycle (Lauersen \& Whitney 1980: 192). The numbers 7, 14 and 21 repeated in Permian bronze casts (e.g. Figures 57-58) must have figured in women's mind. The number 10 is most probably connected with the duration of pregnancy since no credible connection can be found in men's world. Thus the motifs of bronze casts are very closely connected with women's life. Here are

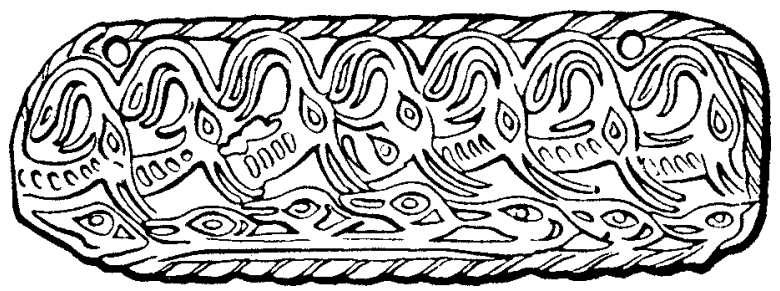

Figures 57-58. The numbers 7, 14 and 21. 57 (top) - bronze plaque. $7+7=14$ (Spitsyn 1906: 147). 58 (bottom) $-7+7+7=21$ (Spitsyn 1906: 148).

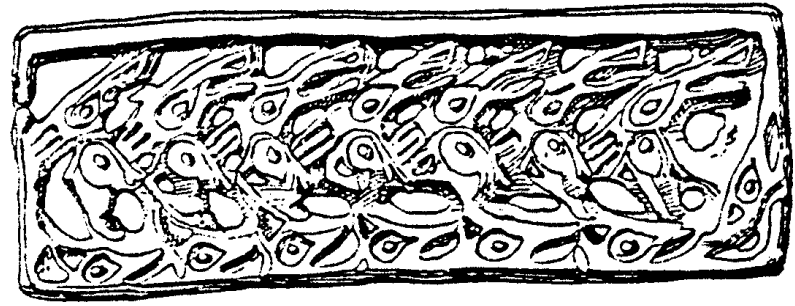


symbolically expressed the best time for conception and the duration of pregnancy. In support of my explanation stands also the fact that namely women have cast bronze both for adornments as well as religious purposes (Golubeva 1984; Rozenfeldt 1987: 151).

\section{CULTURAL HERITAGE COMPARABLE TO THE EPIC "KALEVALA"}

Permian peoples, not to mention the Ob-Ugrians, have cultural heritage comparable with the Finnish epic "Kalevala". Understanding these verses cast in bronze has and will take a lot of research. In the past 100 years, many motifs have attained plausible explanations. Among these is the motif of waterfowl - to borrow Estonia's ex-president Lennart Meri's expression, Finno-Ugrians are the "people of the waterfowl". The motif with two waterfowl depicts Jen and Omöl, the sons of the Chöz-duck. Two animals with their muzzles touching most probably depict marriage between spouses from different totem groups. Totemism is also hinted at in medallions depicting the head of a bear, its paws beside its snout. This could be induced from the Ob-Ugrian belief that bear was the daughter of a heavenly god, sent on Earth for disobedience.

The sulde-motif and the general bird motif with spread wings and a face placed on its chest could originate from the time of the earliest casts and depict totemistic groups (Figures 21 and 29). Still, both motifs have features referring to beliefs, as for example the facing elk heads alone work to inspire security. This is especially noticeable in pictures cast on the occasion of birth of a child. Cast motifs show an easily observable developmental tendency towards humanfaced god-beings and goddesses.

The fact that the culture reflected in Permian bronze casts is closely connected with women is significant. Among other things, this is reflected in the fact that many motifs, such as the waterfowl, female rider and tree of life, can be found in women's handicraft works even as far as in Vepsa and Karelia. Despite this, bronze casts have been part of men's cult objects, as indicated by a neck pendant found from burial 133 in the Kuzmino cemetery in Udmurtia (Ivanova 1992: Ill. 54). 


\section{Comment}

${ }^{1}$ For detailed analysis of the Meandash legends see Ernits 1999 and 2000.

${ }^{2}$ Oiateva has, too, conducted profound research on the meaning and development of the symbolic language of Permian casts (see, e.g. Oiateva 1998a; 1988b).

\section{References}

Anuchin, D. N. 1899. K istorii i verovanii u Priuralskoi chudi. Materialy po arkheologii vostochnykh gubernii Rossii. Moskva.

Appelgren-Kivalo, Hj. 1912. Die Grundzüge des Skytisch-permischen Ornamentstiles. Soumen Muinaismuistoyhdistyksen Aikakauskirja XXVI.

Aspelin, J. R. 1877-1884. Antiquités Nord Finno-Ougrien. Helsinki.

Autio, E. 1981. Karjalan kalliopiirrokset. Keuruu.

Autio, E. 1995. Horned anthropomorphic Figures in Finnish Rockpaintings. Shamans or something else? Fennoscandia archaeologica, XII. Helsinki.

Autio, E. 2000. Kotkat, Hirvet, Karhut. Permiläistä pronssitaidetta. Jyväskylä.

Charnoluski, V. V. 1965. Legenda ob olene-cheloveke. Moskva.

Chesnokova $1995=$ Tšesnokova N. N. The Myth of the Northern SubUrals. Folk Belief Today. Tartu.

Chesnokova N. N. 1988. Klassifikatsii i tipologizatsii v izuchenii arkheologicheskikh istochnikov (na materiale finno-ugorskov izobrazitelnogo iskusstva). Syktyvkar.

Chizhova, L. V. 1982. K voprosu ob ideologii srednevekovogo naselenia Prikamia. Sovetskaia arkheologia, 3.

Chizhova, L. V. 1987. Kultovoe litie lesnoi polosy Evrazii v sisteme animisticheskikh predstavleni ugro-samoditsev. Novye arkheologicheskie issledovania na territorii Urala. Izhevsk.

Ernits, E. 1999. Folktales of Meandash, the Mythic Sami Reindeer. Part 1. Folklore, 11.

Ernits, E. 2000. Folktales of Meandash, the Mythic Sami Reindeer. Part 2. Folklore, 13.

Formozov, A. A. 1969. Ocherki po pervobytnomu iskusstvu. Naskalnye izobrazhenia $i$ kamennye izvaiania epokhi kamnia $i$ bronzy na territorii SSSR. Moskva.

Frolov, B. A. 1974. Chisla v grafike paleolita. Novosibirsk.

Golubeva, L. A. 1966. Konkovye podveski Verkhnego Prikamia. Sovetskaia arkheologia, 3.

Golubeva, L. A. 1978. Simvoly solntsa v ukrasheniakh finno-ugrov. Drevniaia Rus i slaviane. Moskva. 
Golubeva, L. A. 1979. Zoomorfnye ukrashenia finno-ugrov. Moskva.

Golubeva, L. A. 1984. Zhenshchiny liteishchitsy. Sovetskaia Arkheologia, 4.

Gribova, L. S. 1972. Slozhnyi obraz permskogo zverinogo stilia. Etnografia i folklor komi. Syktyvkar.

Gribova, L. S. 1975. Permski zverinyi stil: Problemy semantiki. Moskva.

Gribova, L. S. 1984. Kultovaia plastika Heibida-Pedary. Arkheoloetnograficheskie aspekty Severnogo Priuralia. Syktyvkar.

Gurina, N. N. 1956. Oleneostrovski mogil'nik. Materialy $i$ issledovania po arkheologii SSSR, 47. Moskva \& Leningrad.

Holmberg, U. 1914. Permilaisten uskonto. Porvoo.

Huurre, M. 1983. Pohjois-Pohjanmaan ja Lapin esihistoria. Kuusamo.

Ilina, I.V. 1994. Glava 11 (Iskusstvo). Traditsionnaia kultura naroda Komi. Syktyvkar.

Komi 1992 = Komi yözkostsa iskusstvo/Narodnoe iskusstvo Komi. Moskva.

Korepanov, K. I. 1978. K istorii izuchenia zverinogo stilia Prikamia. Problemy istorii dokapitalicheskikh formatsi. Moskva.

Korepanov, K. I. 1995. Otrazhenie predstavleni o dreve zhizni v iskusstve permskogo zverinogo stilia. Kraevecheskii sbornik. Naberezhnye Chelny. Tatarstan.

Kosarev, M. F. 1984. Zapadnaia Sibir v drevnosti. Moskva.

Lauersen, N. \& Whitney, S. 1980. Nainen - tunne itsesi. Gynekologia ja sukupuolieläma. (Orig: It's Your Body. A Woman's Guide to Gynecology) Keuruu.

Nalimov, V. P. 1907. Zagrobnyi mir po verovaniam zyrian. Etnograficheskoe obozrenie, LXXII-LXXIII. Moskva.

Oborin, V. A. \& Chagin, G. N. 1988. Chudskie drevnosti Rifea. Permski zverinyi stil. The Animal Style of Perm. Perm.

Obydennov, M. F. \& Korepanov, K. I. 1997. Iskusstvo Urala i Prikamia. Epokha kamnia i bronzy. Ufaa.

Oiateva, E. I. 1998a. Yazyk iskusstva. Arkheologicheskii sbornik 33. Sankt-Peterburg: Ermitazh.

Oiateva, E. I. 1998b. "Darstvennye platiny" v khudozhestvennoi metallicheskoi prikamia I - nachala II tysiacheleita n. e. Arkheologicheskii sbornik 33. Sankt-Peterburg: Ermitazh.

Rozenfeldt, R. L. 1987. Prikamskie finny. Finno-ugry i balty v epokhu srednevekovia. Arkheologia SSSR. Moskva.

Rybakov, B. A. 1979. Kosmogonicheskaia simvolika "Chudskikh" shamanskikh bliashek i russkikh vyshivok. Finno-ugry i slaviane. Doklady pervogo Sovetsko-Finliandskogo simposiuma. Leningrad.

Shmidt, A. V. 1927. K voprosu o proiskhozhdenii Permskogo zverinogo stilia. Sbornik Muzea Antropologii i Etnografii. Leningrad. 
Shutova, N. I. 1998. Zhenskoe bozhestvo plodorodia v dukhovoi zhizni finno-ugrov Priuralia. Ob etnicheskoi psikhologii udmurtov. Izhevsk.

Sidorov, A. S. 1972. Ideologia drevnego naselenia Komi kraia. Etnografia i folklor Komi. Syktyvkar.

Smirnov, A. P. 1952. Ocherki drevnei i srednevekovoi istorii narodov Povolzhia i Prikamia. Materialy i issledovania po arkheologii SSSR, 28. Moskva.

Spitsyn, A. A. 1899. Shamanizm v otnoshenii k russkoi arkheologi. Zapiski Russkogo arkheologicheskovo obshchestva. XI:I, II.

Spitsyn, A. A. 1906. Shamanskie izobrazhenia. Zapiski Otdelenia russkoi slavianskoi arkheologii Russkogo arkheologichestkogo obshchestva, VII:1. Sankt-Peterburg.

Studzitskaia, S. V. 1994. Neoliticheskie ritualnye "zhezly" lesnoi polosy Evrazii. Mezhdunarodnaia konferentsia k 100-letiu V. I. Ravdonikasa. Tez. dokladov Gosudarstvennogo Ermitazha. Sankt-Peterburg.

Tallgren, A. M. 1931. Luoteis-Siperian kulttuurikosketuksista Kr. s. aikaan. Kalevalaseuran vuosikirja 11. Porvoo.

Tallgren, A. M. 1934. Die Altpermische Pelzwarenperiode an der Petšora. Suomen Muinaismuistoyhdistyksen Aikakauskirja, XL.

Teploukhov, F. A. 1893. Drevnosti Permskoi Chudi v vide basnoslovnykh liudei i zhivotnykh. Permski krai. Perm.

Zbrueva, A. V. 1952. Istoria naselenia Prikamia v ananinskuiu epokhu. Materialy $i$ issledovania po arkheologii SSSR, 30. Moskva. 